\title{
COMPARISON OF OPERATOR MEAN GEODESICS
}

\author{
Jun ICHI FuJII, JADRANKA MićIć, JOSIP PEČARIĆ AND YUKI SEO
}

Abstract. The space of positive invertible operators of a unital $\mathrm{C}^{*}$-algebra has a natural structure of reductive homogenious manifold with a Finsler metric. Then pairs of points $A$ and $B$ can be joined by a natural geodesic $A \sharp t B=A^{\frac{1}{2}}\left(A^{-\frac{1}{2}} B A^{-\frac{1}{2}}\right)^{t} A^{\frac{1}{2}}$ for $t \in[0,1]$, where is the geometric mean in the sense of Kubo and Ando. In this paper, we consider estimates of the upper bounds for the difference between the geodesic and extended interpolational paths by terms of the spectra of positive operators. As applications, we investigate some properties of the velocity vectors for interpolational paths. Also, we obtain estimates of the upper bounds for $\alpha$-operator divergence as a noncommutative version of the $\alpha$-divergence in the information geometry.

Mathematics subject classification (2000): 47A63, 47A64.

Key words and phrases: Operator inequality, Interpolational path, Mond-Pečarić method, Operator mean, geodesics, $\alpha$-divergence.

\section{REFERENCES}

[1] S. AmARI, Differential Geometrical Methods in Statistics, Springer Lecture Notes in Statistics, 28 (1985).

[2] E. Andruchow, G. CoRACH, D. StojanofF, Geometrical significance of the Lowner-Heinz inequality, Proc. Amer. Math. Soc., 128 (1999), 1031-1037.

[3] V. P. BELAVKIN, P. STASZEWSKI, $C^{*}$-algebraic generalization of relative entropy and entropy, Ann. Inst. H. Poincaré Sect., A.37 (1982), 51-58.

[4] G. CORACH, H. PORTA, L. RECHT, Geodesics and operator means in the space of positive operators, Int. J. Math., 4 (1993), 193-202.

[5] G. CORACH, H. PORTA, L. RECHT, Convexity of the geodesic distance on spaces of positive operators, Illinois J. Math., 38 (1994), 87-94.

[6] J. I. FUJII, On the relative operator entropy (in Japanese), RIMS Kokyuroku 903 (1995), 49-56.

[7] J. I. FUJII, The Corach-Porta-Recht theorem and operator means, preprint.

[8] J. I. FUJII, M. FUJII, Y. SEO, Bounds for interpolational path of positive operators, Recent Topics on Operator Inequalities, RIMS Kokyuroku, 1359 (2004), 46-57.

[9] J. I. FUJI, E. KAMEI, Relative operator entropy in noncommutative information theory, Math. Japon., 34 (1989), 341-348.

[10] J. I. FUJII, E. KAMEI, Uhlmann's interpolational method for operator means, Math. Japon., 34 (1989), $541-547$

[11] T. Furuta, J. Mićić, J. E. PeČARIĆ, Y. SEO, Mond-Pečarić Method in Operator Inequalities, Monographs in Inequalities 1, Element, Zagreb, 2005.

[12] E. KAMEI, Paths of operators parametrized by operator means, Math. Japon., 39 (1994), 395-400.

[13] F. Kubo, T. Ando, Means of positive linear operators, Math. Ann., 246 (1980), 205-224.

14] M. NAKAMURA, H. UMEGAKI, A note on the entropy for operator algebras, Proc. Japan. Acad., 37 (1961), 149-151. 